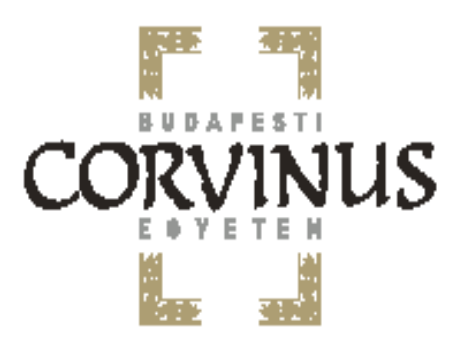

Politikatudományi

Doktori Iskola

\title{
TÉZISGYÜJTEMÉNY
}

\section{Dobos Gábor}

A magyar önkormányzati rendszer autonómiájának empirikus elemzése

címủ doktori értekezéséhez

Témavezető:

Várnagy Réka, PhD 



\section{Tartalomjegyzék}

I. Kutatási előzmények és a téma indoklása................................................................. 3

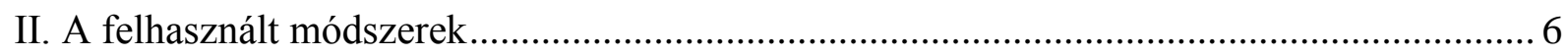

II.1. A helyi autonómia mértékének mérése intézményi szinten ................................. 6

II.2. A helyi politika szervezeti szintje - országos és helyi pártok ............................... 7

II.3. A helyi politika egyéni szintje - horizontális viszonyok ................................... 9

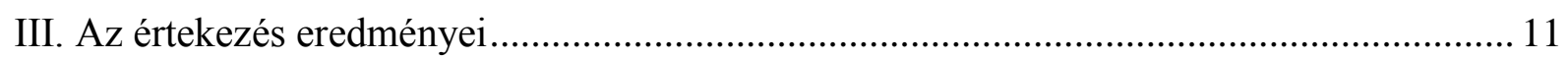

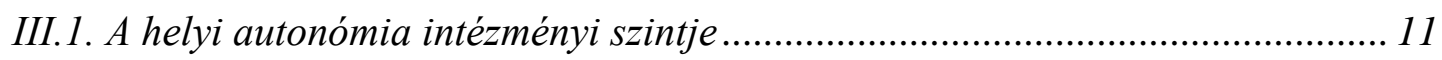

III.2. A helyi politika szervezeti szintje …........................................................... 13

III.3. A helyi politika egyéni szintje - horizontális viszonyok .................................. 16

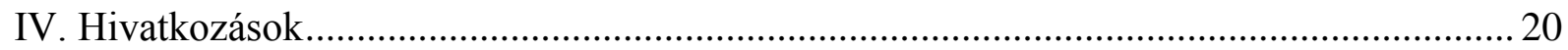

V. A szerző témában megjelent publikációi...................................................................... 21 


\section{Kutatási előzmények és a téma indoklása}

1990-ben Magyarországon egy olyan decentralizált önkormányzati rendszer jött létre, amely a demokrácia egyik fontos építőelemét jelentette: a helyi önrendelkezés jegyében, az „egy település - egy önkormányzat" elvére épülő rendszer a központi kormányzat ellenpontjának (és egy potenciálisan visszatérő autoriter rezsim megakadályozása biztosítékának) ígérete lett. Az új önkormányzati szabályozás kialakításában alapértékként jelent meg a helyi autonómia, melynek fontosságát, a települések önkormányzáshoz való jogát 1990-től kezdve senki (semmilyen kormány vagy politikai erő) nem vonta kétségbe nyíltan. Miközben a kialakított rendszer problémái nagyon hamar világossá váltak, a minden településre kiterjedő helyi autonómia elve a rendszerváltást követő húsz évben sokszor szabta gátját a rendszer racionalizálási kísérleteink: ha a központi kormányzat megpróbált beavatkozni az önkormányzati müködésbe az adminisztratív vagy közszolgáltatási funkció átalakításával, azt a mindenkori ellenzék az autonómia megsértéseként értékelte. Átfogó reformra (kétharmados parlamenti többség és/vagy egységes politikai akarat hiányában) nem volt lehetőség, az ágazati szabályok módosítása pedig nem volt alkalmas a rendszer strukturális problémáinak orvosolására, így az 1990-ben létrejött önkormányzati rendszer húsz éven át többé-kevésbé változatlan keretét adta a helyi és regionális szintek működésének.

Ez a helyzet 2010-től változott meg, amikor a Fidesz-KDNP pártszövetség földcsuszamlásszerü országgyülési választási győzelme után - a politika más alrendszereihez hasonlóan - gyökeres átalakításokba kezdett az önkormányzati szférát illetően. A 2010 és 2014 között zajló reformfolyamatok jelentősen átszabták a korábban kialakult képet, megváltoztatva a szubnacionális szféra politikai és funkcionális (feladatellátási, finanszírozási stb.) müködését egyaránt. Az átalakítás során az önkormányzati autonómia fontosságát a törvényhozók nem kérdőjelezték meg, bár deklarálták, hogy a magyar önkormányzatok nagy autonómiája (legalább részben) felelős a rendszer müködési zavaraiért. Az önkormányzati rendszer átalakítása formailag nem érintette az önkormányzatok autonómiáját, de a reformok alapján lehet amellett érvelni, hogy az önkormányzatok mozgástere a gyakorlatban csökkent.

A 2010-es évtől kezdődően a magyar szakirodalom viszonylag széles körben foglalkozott az önkormányzati rendszer reformjával, számos olyan írás jelent meg, amely a változásokat mutatta be és értékelte. Ezek a munkák legtöbbször a reformok deskriptív feldolgozásait adták, a jogszabályok változásaiból indultak ki, és ezekből vontak le következtetéseket a rendszer (várható) müködésére nézve. Dolgozatom is a változás megragadására törekszik, de munkámban az önkormányzati rendszer empirikus elemzésére vállalkozom. Munkám során az 
autonómia fogalmát állítom a középpontba, arra a kérdésre keresem a választ, hogy hogyan változott az önkormányzati rendszer autonómiája Magyarországon? Az autonómia fogalma azért alkalmas a változások megragadására, mert magába foglalja az intézményrendszer formális szabályait, az önkormányzatok tényleges müködési gyakorlatát és az önkormányzati rendszer szereplöinek viszonyrendszerét is.

Dolgozatom arra vállalkozik, hogy a legújabb nemzetközi önkormányzati kutatások módszertani eszköztárával elemezze a magyar politikai rendszer szub-nacionális (helyi és regionális) szféráját, a disszertációban három (részvételemmel zajló) nemzetközi projekt elemzési módszereit és eredményeit használom a kérdés vizsgálatára, saját adatgyüjtéssel és elemzéssel kiegészítve. A nemzetközi, különböző országok önkormányzati rendszereinek összehasonlítására kidolgozott kutatási keretek éppen abból adódóan jelentenek többletet a téma vizsgálatában, hogy egyfajta „távolságtartással” tekintenek a magyar önkormányzati rendszerre, a teljes képet próbálják megragadni, és nem vesznek el a részletekben (amire belülröl nézve a rendszert, nagyobb az esély). Az összehasonlító keret lehetőséget nyújt arra, hogy az önkormányzati rendszer változását ne csak leíró módon, két időpont közötti különbségként értelmezzem, hanem egy európai viszonyrendszerben értékeljem a rendszer müködését. Amellett, hogy a nemzetközi keretek megfelelő viszonyítási alapot jelentenek a magyar önkormányzati rendszer autonómiájának értékeléséhez, fontosnak tartom, hogy ne vesszen el a rendszer „egyedisége” sem. Éppen ezért kvantitatív kutatási megközelítésekkel kialakított felülnézeti kép mellett a dolgozatban megjelenik a kvalitatív módszereket alkalmazó alulnézeti perspektíva is.

A dolgozat elméleti fejezetében hosszabban foglalkozom az autonómia fogalmával, illetve azzal, hogy milyen empirikusan vizsgálható tényezők összességeként ragadható meg az önkormányzati rendszer autonómia-szintje. Page és Goldsmith (1987) munkája alapján úgy érvelek, hogy az önkormányzati autonómiát meghatározó tényezők:

- az intézményi berendezkedés (alkotmányos keretek és törvények)

- helyi szint által ellátott feladatok

- a feladatellátás terén az önkormányzatok diszkrecionális jogai a döntéshozatalban

- a feladatellátáshoz társított pénzügyi források

- a felsőbb szintek befolyásolásának képessége.

A szakirodalom alapján az intézményi keretekből indulok ki, de vizsgálom az önkormányzatok gyakorlati mozgásterét is (a feladatellátás és a pénzügyi függetlenség terén), illetve külön figyelmet fordítok az intézményrendszer szereplöire. Utóbbira azért van szükség, mert a helyi és országos politika viszonyrendszere nemcsak az intézményeken és azok gyakorlati 
müködésén keresztül értelmezhető, az összefonódás politikailag is megvalósul. Ahhoz, hogy az önkormányzatok valós politikai ellensúlyt képviseljenek a rendszerben, saját politikai autonómiájuk kell, hogy legyen. A politikai önállóság első és legegyszerübb fokmérője az önálló helyi politikai akarat megléte vagy hiánya, azaz, hogy a helyi politika mennyire tükrözi és követi az országos politikai viszonyokat vagy mennyire tér el azoktól. Az országos politikába belesimuló helyi szint gyengíti a politikai ellensúly kialakításának lehetőségeit még az egyébként magas autonómiával rendelkező intézmények esetén is.

A dolgozat tehát alapvetően neo-institucionalista megközelítést alkalmaz, mely elutasítja az intézmények száraz, formális, jogi/alkotmányos keretekre támaszkodó leíró elemzését (Sweeting 2008: 1). Az irányzat a formális jogkörök mellett az informális müködési szokások fontosságát is hangsúlyozza, azt is vizsgálja, hogy az intézmény szereplői milyen hatalmi viszonyban állnak egymással, illetve nem csak az intézmények egyénekre való hatását elemzi, de arra is kíváncsi, hogy az egyének hogyan formálják az intézményrendszer kínálta kereteket (Lowndes 2001: 1953). A neo-institucionalizmus szerint tehát az egyének viselkedése szempontjából a formális szabályok mellett ugyanolyan fontosak az informális, gyakorlati müködés során kialakuló szabályok is. Így az önkormányzati rendszer működését nem csak az intézményi keretek határozzák meg, hanem a kereteket „élettel megtöltő” szereplők is (Heinelt 2010: 32). 


\section{A felhasznált módszerek}

A dolgozat egy kutatási terület komplex elemzésére vállalkozik. Ahhoz, hogy a kutatási téma több aspektusát meg tudjam ragadni, a kevert módszerek (,mixed methods”) módszertanát alkalmazom, mely a kvalitatív és kvantitatív kutatási megközelítések elemeit ötvözi, ezzel egyszerre próbálja kihasználni a kvantitatív kutatások fókuszáltságából és a kvalitatív kutatások feltáró jellegéből származó előnyöket (Király et al 2014: 96). A megközelítés segítségével a kutatás több nézőpontot, perspektívát tud egymás mellé helyezni (Johnson et al 2007: 113). Ennek megfelelően a dolgozatban a kevert módszerü kutatás elvei alapján kvantitatív és kvalitatív kutatási módszereket is alkalmazok.

Az empirikus kutatás első szintje az önkormányzati intézményrendszer átfogó, kvantitatív elemzése. Ennek során az intézményi berendezkedésből indulok ki, de az elemzés túlmutat a jogszabályi keretek ismertetésén, a tényleges autonómia/mozgástér kérdését is vizsgálja, az autonómia szintjét mérő mutatókban pedig megjelennek a gyakorlati müködésre vonatkozó indikátorok is. Az empirikus elemzés második szintje az önkormányzati rendszer szervezeti szereplőire (országos és helyi pártok, civil szervezetek) fókuszál, szintén kvantitatív megközelítésben - egyrészt kérdőíves kutatások adataival dolgozom, másrészt választási eredményeket elemzek. Az elemzés harmadik szintjén az egyénekkel foglalkozom, kvalitatív megközelítésben: a helyi szereplők viszonyainak feltérképezéséhez félig strukturált interjúkat használok.

\section{II.1. A helyi autonómia mértékének mérése intézményi szinten}

Ahhoz, hogy a magyar önkormányzati autonómia mértékét (és ezen keresztül az önkormányzati reformok hatásait) mérni tudjuk, egy olyan mérőszámra van szükség, ami egyszerre ragadja meg az intézményi aspektust (azaz az önkormányzatok politikai rendszeren belüli helyét) és képes leírni a tényleges müködést is. Azaz a mérőszámnak meg kell ragadnia a helyi autonómia és decentralizáció Page és Goldsmith (1987) munkáján keresztül bemutatatott tényezőit: az intézményi-alkotmányos helyzetet, a feladatok körét, a feladatellátás önállóságát és a pénzügyi függetlenséget. Ha az autonómiát e dimenziók összességeként értelmezzük, akkor a komponensekből létrehozható egy index.

Munkám során egyrészt használom a fenti dimenziók megragadására 2008-ban készült, komplex „Regional Authority Index” (RAI) mutatót, amely egy nemzetközi kutatási projekt (Hooghe et al 2010) keretében negyvenkét demokrácia középszintű önkormányzatának 
önrendelkezési szintjét és annak változásait vizsgálja hatvan éves időtávon (1950-2010 között). A kutatás célja annak megragadása, hogy mekkora a regionális önkormányzatok tényleges autoritása: nem csak az adott önkormányzatok intézményi beágyazottságából fakadó (névleges) önrendelkezését kívánja mérni, de az elsősorban pénzügyi eszközökön keresztül megvalósuló valós mozgásterét is. A RAI mérőszámának kialakítása a decentralizáció szakirodalmában bevett „self-rule” és „shared-rule” kettősségre épít: előbbi azt mutatja meg, hogy a regionális önkormányzat mennyire független végrehajtó a saját terültén, utóbbi pedig azt, hogy az önkormányzat mennyire képes befolyásolni a központi döntéshozatalt. A kutatás mindkét aspektushoz öt-öt indikátort rendel, ezzel reflektálva az intézményi helyzetre és a tényleges müködési környezetre egyaránt.

Dolgozatomban a helyi szint autonómiájának mérésére a „Local Authority Index” (LAI) mutatót használom, mely a regionális önkormányzatokra kialakított módszertanra épít, és célja az autonómia mértékének (illetve változásának) mérése a helyi önkormányzatok önrendelkezésének vizsgálatán keresztül (Ladner et al 2016). A kutatásban összesen 39 ország helyi önkormányzati autonómiájának mértékét vizsgálták az 1990 és 2014 közötti időszakban. A RAI projekthez hasonlóan Magyarország is a vizsgált estek között volt, a LAI mérőszám kódolását Pawel Swianiewicz (University of Warsaw) irányítása alatt én végeztem. A kutatás a regionális index továbbfejlesztésével igyekszik szofisztikáltabb mutatószámot kialakítani a helyi autonómia mérésére azáltal, hogy szétválasztja a formális és tényleges müködést. A LAI sokkal nagyobb hangsúlyt fektet az önkormányzatok pénzügyi mozgásterére is, így a kutatás összesen nyolc „self-rule” és három „shared-rule” típusú indikátorral méri az autonómia szintjét.

A dolgozatban amellett érvelek, hogy a LAI és RAI mutatók (illetve az indexeket alkotó komponensek, az önrendelkezés egy-egy aspektusát megragadó indikátorok) képesek leírni az önkormányzati autonómia intézményi szintjét, továbbá az önkormányzati (gyakorlati) müködés lehetőségeit és korlátait.

\section{II.2. A helyi politika szervezeti szintje - országos és helyi pártok}

Az elemzés második szintje a helyi és középszintü intézményrendszer szervezeti szereplöire (pártok, társadalmi szervezetek) fókuszál. Habár a hazai politikatudományi szakirodalom elsősorban az országos szint felől közelít a szervezetek empirikus elemzéséhez, dolgozatomban ismertetek három olyan munkát (Soós 2008, 2015; Tóth 2013), melyek a kvantitatív kutatások eszköztárával megpróbálják értelmezni a helyi politika szerveződését. Ezek a kutatások a 
választási eredményeket, és az ebből fakadó képviselő-testületi mandátumarányokat vetik össze az egyes települések szocio-demográfiai adataival (településméret, etnikai összetétel stb.), és regressziós modellek segítségével arra az alapvető kérdésre keresik a választ, hogy mitől függ az országos pártok helyi politikában való megjelenése. A kérdés megválaszolásával makrováltozókon keresztül képet kaphatunk arról, hogy mi befolyásolja a politikai szervezetek részvételét a helyi politikában.

A dolgozat azonban elsősorban a középső szint empirikus elemzéséhez kíván új eredményeket hozzátenni, mivel ez lényegében hiányzik a hazai szakirodalomból. Munkám során amellett érvelek, hogy Magyarországon a regionális (megyei) szintű politika - az abban részt vevő szervezeteken keresztül - szorosan összefügg a helyi politikával, emiatt a regionális politika megismerése hozzátesz a helyi politika szervezeti aspektusának megértéséhez. A megyei politika esetében szintén választási eredmények kerülnek a középpontba. Az elemzés első lépéseként az intézményi keretekből indulok ki, az intézményrendszer változásának hatásaira fókuszálok, mivel Magyarországon (a választási rendszer átalakításával) alapvetően változtak meg 2010-ben azok az intézményi keretek, melyek között a középszintű szereplőknek müködnie kell. Jelöltállítási adatokra támaszkodva demonstrálom, hogy a választási rendszer átalakítása milyen drasztikus változást idéz elő a középszintű politikában, hogyan alakítja át az országos és regionális (de ahogy azt a dolgozatban bemutatom, valójában helyi) pártok viszonyait. Az elemzés következő lépéseként választási eredmények elemzésével, egy nemzetközi projekt (Schakel 2017) kutatási kereteinek, illetve a változás leírására használt fogalmainak (nacionalizáció és a regionalizáció) segítségével megpróbálom megragadni a magyar középszintü politika átalakulásának folyamatait. A dolgozatban bemutatott projekt arra tesz kísérletet, hogy a közép- és kelet-európai országok regionális politikai színtereinek dinamikáját komparatív módon feltárja - a magyar regionális szint elemzését Várnagy Rékával közösen végeztem. A kutatás kiinduló kérdése, hogy mennyire illeszkednek az egyes országok regionális politikai eseményei az úgynevezett másodrendü választások (,second order elections”) irodalmának feltételezéseihez. Ha a regionális választások a másodrendű választások jeleit mutatják, akkor a középszintű politika nacionalizációja figyelhető meg, mivel a választók arra használják fel a szavazatukat, hogy a parlamenti választásokon győztes kormányzó pártok munkájáról mondjanak ítéletet. A regionalizáció folyamatáról pedig akkor beszélhetünk, ha a regionális választási versenyt nem az országos politika logikája határozza meg, és a középszintü választásokon a regionális pártok is sikerrel tudnak szerepelni. A szavazatarányok ingadozásának mérésére a kutatás az úgynevezett különbözőségi indexet (,dissimilarity index”) használta, amely lényegében azonos Pedersen (1979) választói 
illékonyságot (volatilitást) mérő indexével, de a politikai szervezetek választási teljesítményének (szavazatarányának) változását nem két parlamenti választás eredményének, hanem a parlamenti és regionális választások eredményeinek összehasonlításával méri. A módszer tehát alkalmas arra, hogy az eddig kevéssé kutatott középszinten vizsgálja az önkormányzati rendszer szervezeti szereplöit. Mivel a kutatás a magyar önkormányzatiság teljes időhorizontját lefedi (azaz az első megyei önkormányzati választásoktól a 2014-es évig terjedően elemzi az eredményeket), képes arra, hogy a kutatásban alkalmazott két lehetséges folyamaton, a nacionalizáción és a regionalizáción keresztül megragadja az intézményrendszer és szereplői helyzetének változását.

\section{II.3. A helyi politika egyéni szintje - horizontális viszonyok}

Az empirikus elemzés harmadik szintje a helyi politika egyéni szereplöire fókuszál. A vizsgálat két részből áll. Első lépésként azt a kérdést teszem fel, hogy hogyan is néznek ki a helyi szint horizontális viszonyrendszerei. A kérdés megválaszolásához az intézményi keretekből indulok ki, ismertetem a szereplők formális szabályokon alapuló viszonyait, és egy (részben általam végzett) kvantitatív és kvalitatív megközelítéseket egyaránt alkalmazó, kérdőíves felmérésen alapuló kutatás segítségével azt vizsgálom, hogy a gyakorlatban hogyan alakul a szereplők egymáshoz való viszonya az intézményi keretekhez képest.

A helyi szereplők viszonyaira fókuszáló elemzés második lépése a változás megragadására irányul. Mivel az elemzésnek ez a szintje a helyi szereplőkön keresztül igyekszik megragadni az önkormányzati autonómiát, az empirikus vizsgálat az egyéni szereplők változással kapcsolatos percepcióira épül, munkám során két, percepciók feltárására irányuló kutatás eredményeire támaszkodom. Elsőként, egy 2013 januárja és áprilisa között zajló (kvalitatív) interjús kutatás eredményeit ismertetem. Az adatfelvétel során félig strukturált interjúkkal arról kérdeztünk polgármestereket és jegyzőket, hogy ők mit tekintenek az önkormányzati reform legfontosabb lépéseinek és hatásainak. Másodszor, egy (részben általam végzett) nemzetközi kérdőíves kutatás (Political Leaders in European Cities - POLLEADER) adataira támaszkodva azt vizsgálom, hogy a 2010 utáni önkormányzati reform hogyan alakította át a szereplők egymáshoz való viszonyát. Mivel az adatfelvétel két hullámban (2003-ban, az önkormányzati reform előtt, illetve 2015-ben, az átalakítást követően) zajlott, az adatok (a dolgozatban ismertetett megszorításokkal) alkalmasak a változás megragadására. Az elemzés fókuszában a polgármesteri pozíció áll, az adatokon keresztül arra a kérdésre keresem a választ, hogy az intézményrendszerben bekövetkező változások megjelennek-e a polgármesterek 
percepcióiban. Az átalakítás hatásait hasznos a polgármesterek személyén keresztül megvizsgálni, mivel a polgármesterek azok a szereplők, akik egyszerre tudnak képet alkotni az önkormányzatok vertikális hatalommegosztáson belüli helyzetéről és az önkormányzaton belüli, horizontális viszonyrendszert érintő változásokról.

Összességében tehát, az empirikus elemzés mindhárom szintjén (intézményi szint, szervezeti szereplők, egyéni szereplők) az intézményrendszer gyakorlati működését vizsgálom a kevert módszerek módszertanának eszköztárával (kvalitatív és kvantitatív megközelítések egyidejü alkalmazásával). Célom egyrészt annak feltárása, hogy az intézményrendszer adta formális keretek a szereplőkön ,átszürve” hogyan jelennek meg a magyar önkormányzati rendszerben, azaz a szereplők miként hatnak az intézményre, másrészt annak vizsgálata, hogy az intézményrendszer változása miként hat a szereplőkre. 


\section{Az értekezés eredményei}

\section{III.1. A helyi autonómia intézményi szintje}

Az empirikus elemzés első, intézményrendszerre fókuszáló szintjén olyan mutatószámokat alkalmaztam, amelyek segítségével kvantifikálhatóak a szakirodalomban megjelenő, autonómiát befolyásoló tényezők. Az alábbiakban a két mutatószám közül terjedelmi okok miatt csak az autonómia szintjét szofisztikáltabban mérni képes, helyi szintre vonatkozó LAI magyarországi eredményeit mutatom be.

A LAI mutatót alkotó két dimenzió (,self-rule” és „interactive rule”) értékeit összeadva látható, hogy a magyarországi önkormányzatok hol helyezkednek el a két elméleti végpont, az autonómiát teljesen nélkülöző (0) és a teljes autonómiával rendelkező (37) önkormányzatok között. A kutatási keretrendszer szerint a magyar önkormányzati autonómia 1990-ben viszonylag magas szintűnek mondható, széleskörü feladat ellátási lehetőségekkel, ám más téren (szakpolitikai autonómia, pénzügyi helyzet stb.) terén közepes mozgástérrel (1. ábra).

1. ábra: A magyar helyi önkormányzatok LAI mutatójának alakulása (1990-2014)

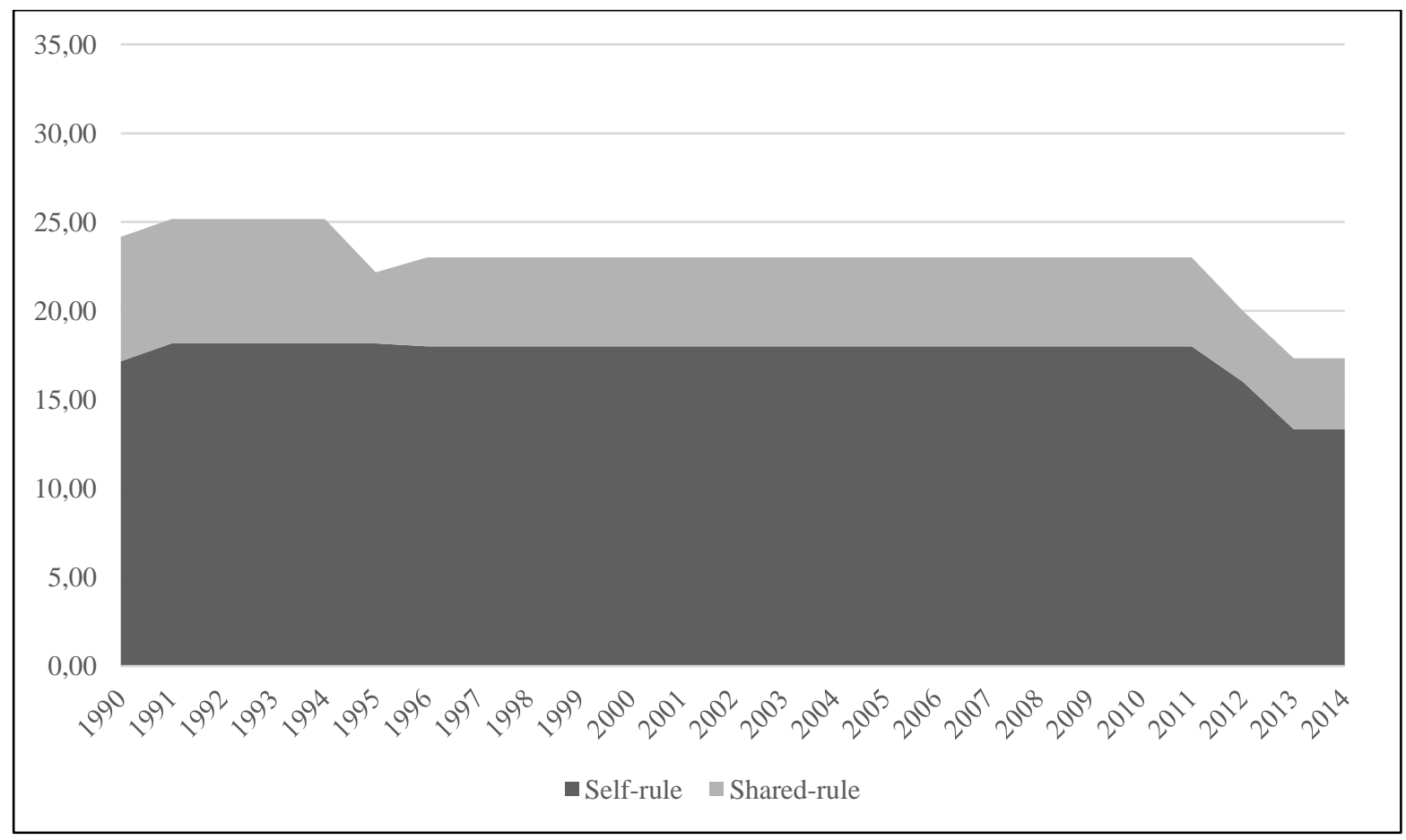

Ha az autonómia mértékének időbeli alakulását vesszük górcső alá, látható, hogy a kezdeti autonómia-szint lényegében két ponton változott, mindkétszer csökkent. Jelentősebb változás 
2011 és 2013 között figyelhető meg, és a rendszer számos pontját érintő kisebb-nagyobb átalakítás eredményeként jött létre.

Az önkormányzatok - névleges és tényleges - szakpolitikai mozgásterének szükülése (az egészségügy, az oktatás és a szociális ellátás területein), a pénzügyi önrendelkezés csökkenése (a feladatfinanszírozás és szigorú hitelfelvételi szabályok bevezetésén keresztül), illetve a központi kormányzat felügyeletének kiterjesztése (az önkormányzatok tényleges jogi felügyeletével) eredményeként a korábbi évekhez képest a LAI mutató alapján negyedével csökkent a magyarországi helyi autonómia mértéke (23 pontról 17,3 pontra).

2. ábra: A magyarországi helyi autonómia nemzetközi összehasonlitásban (1990-2014)

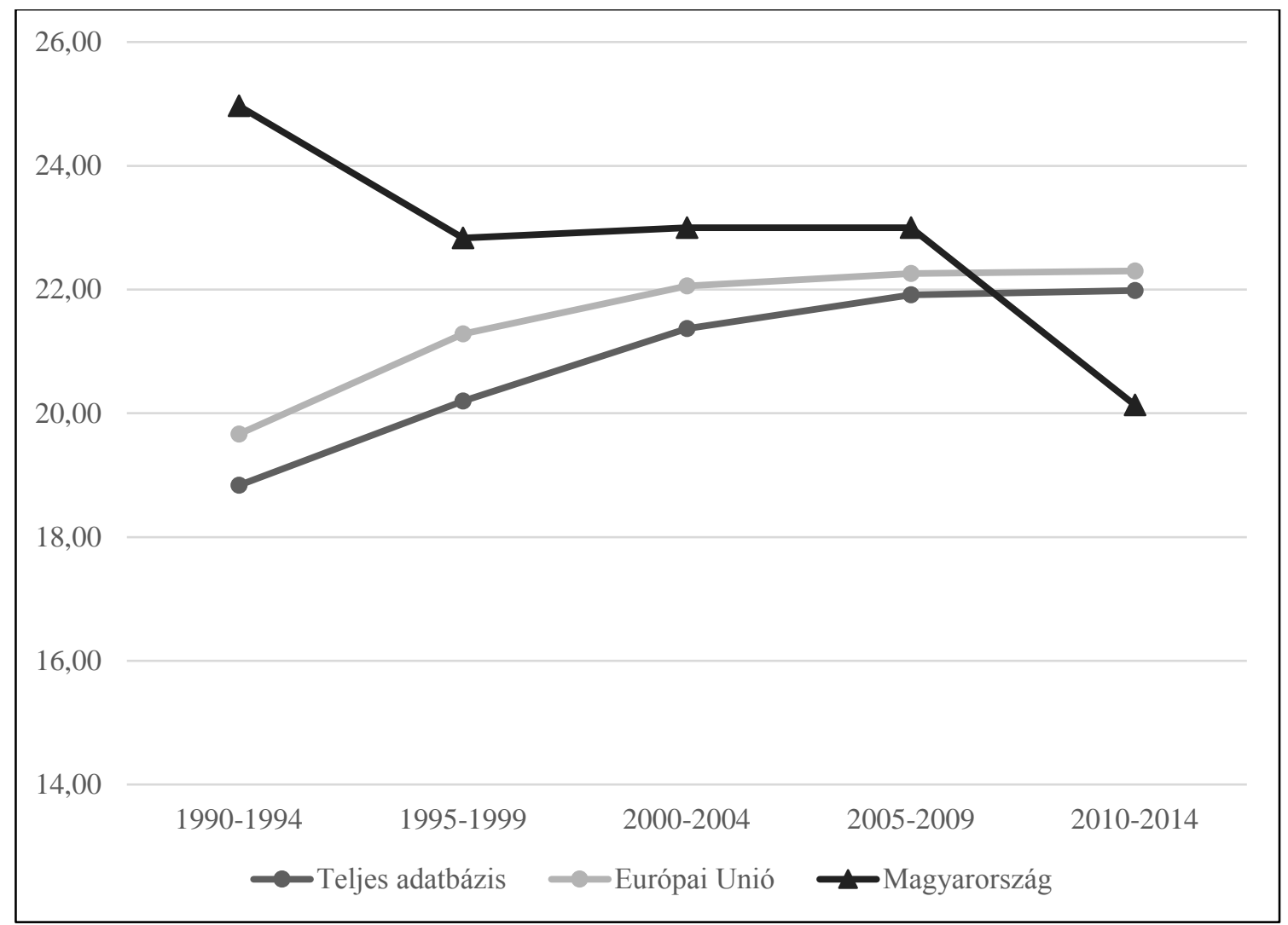

A dolgozatban ismertetett adatok azt mutatják, hogy a rendszerváltás során a magyar önkormányzati rendszer nemzetközi összehasonlításban is széleskörü autonómiával jött létre, harminckilenc állam közül mindössze hét ért el magasabb autonómia szintet, mint a magyar eset. Ezt követően a magyar autonómia ellentétesen mozgott a nemzetközi és európai uniós trendekkel: míg más országokban az autonómia mértéke fokozatosan növekedett az elmúlt 2025 évben, addig Magyarországon inkább csökkent (2. ábra). Úgy tünik, a magyar önkormányzatiság az elmúlt húsz évben veszített autonómiájából, mely folyamat tekinthető 
egyfelől az autonómia hanyatlásaként, de a rendszer konszolidációjaként is. A vizsgálat utolsó időszakára a magyar autonómia mértéke a nemzetközi átlag alá csökkent, és visszaesett a „rangsorban”: mindössze tizenhárom állam autonómia-szintje került a magyar érték alá, köztük olyan nem EU-tag országokkal, mint Albánia, Grúzia, Moldova vagy Törökország. Ha az 19902014 között megtett utat tekintjük, megállapítható, hogy a LAI projekt keretében elemzett 39 ország közül a vizsgált időszakban a magyar önkormányzatiság autonómiájának szintje csökkent a legnagyobb mértékben.

A dolgozatban ismertetett mutatók rávilágítanak arra is, hogy az autonómia vizsgálatához fontos a formális intézményi szabályok ismerete, de nem elegendő. Láthatóvá vált, hogy Magyarországon az önkormányzatok alkotmányos berendezkedésben betöltött szerepében nem történt érdemi változás a dolgozat által vizsgált időszakban, az intézményi keretek lényegében nem változtak, de a gyakorlati mozgástér (a feladatellátás és a pénzügyi függetlenség terén) jelentősen szűkült 2010-től kezdődően, a teljes önkormányzati szférát átfogó átalakítás nyomán. A mutatószámok változása visszaigazolja a magyar szakirodalom álláspontját a rendszer reformjával kapcsolatban: formálisan nem történt változás, de a gyakorlati müködésben az önkormányzati feladatellátás és a pénzügyi autonómia visszaszorulása tapasztalható.

A kvantitatív elemzés, amellett, hogy a rendszer müködésének leírását felülnézetből elvégezte, megmutatta azt is, miért indokolt a magyar önkormányzati rendszer autonómiájának teljes körü feltárásához a neo-intitucionalista megközelítés alkalmazása. Habár az indexek az autonómia számos gyakorlati aspektusának megragadására alkalmasak, az ilyen megközelítésből szükségszerüen hiányzik a „politikai” - amely a formális berendezkedésen túli, informális müködési szokásokon, azaz a szereplők egymáshoz való viszonyain és viselkedésén keresztül ragadható meg. Munkám során amellett érvelek, hogy az önkormányzati rendszer (mint intézmény) autonómiájánál több a helyi autonómia, ebbe a szereplők (legyenek azok szervezetek vagy egyének) politikai autonómiája is beletartozik. Az elemzés következő két szintje ezért a szereplőkre fókuszál, a második szinten a dolgozat a szervezeti szereplőket (pártok, társadalmi szervezetek) vizsgálja, a harmadikon pedig ez egyéni szereplőket, illetve a helyi aktorok horizontális viszonyrendszerét.

\section{III.2. A helyi politika szervezeti szintje}

Az empirikus elemzés második, a politikai autonómiájának szervezeti aspektusával foglalkozó szintjén egy olyan értelmezési keretben vizsgálom a politikai szervezeteket, amely arra a 
kérdésre keresi a választ, hogy a szub-nacionális szinteken a „top-down” vagy a „bottom-up” folyamatok érvényesülnek-e jobban. ${ }^{1}$ A szervezeti szint esetében (kvalitatív kutatási eredmények hiányában) választási eredményekből indulok ki, és azt vizsgálom, hogy a magyar önkormányzatban kezdetektől jelen lévő helyi politika - országos politika szembenállás miként érvényesül.

Az empirikus elemzés visszaigazolja azt az elképzelést, hogy a választási rendszerben alkalmazott, népesség szerinti szétválasztás más-más típusú helyi politikát eredményez. A kisebb településeken a független jelöltek mellett elsősorban a helyi pátok (civil szervezetek) jelenléte meghatározó, a nagyobb településeken viszont az országos pártok kerülnek túlsúlyba. Úgy tűnik, hogy az országos pártok egy bizonyos településméret alatt nem tudnak (vagy nem akarnak) a helyi politika formálói lenni, adott településméret felett azonban az országos politika logikája határozza meg a helyi politika müködését is. Ezek természetesen nem új eredmények. A dolgozat abban kíván hozzájárulni a korábbi kutatásokhoz, hogy a két, egymással ellentétes irányú folyamat találkozását a középszinten vizsgálja. Magyarországon a megyei szint azért megfelelö terep ennek a dinamikának az elemzésére, mert (a dolgozatban bővebben ismertetett tényezők, például regionális pártok ellen ható intézményi berendezkedés, megyei identitás hiánya, helyi és megyei választások időzítése stb. miatt) a megyei politikai aréna a helyi pártok számára is megjelenési lehetőséget biztosít.

A nemzetközi kutatáson alapuló eredmények alapján, a másodrendü választások jellemzőit figyelembe véve megállapítható, hogy a magyar eset vegyes képet mutat: a választási részvétel alacsonyabb a regionális szinten, mint a parlamenti választások esetében, de a kormányzó pártok nem veszítenek szisztematikusan szavazatot az ellenzéki pártok javára a két választás között (3. ábra). A választások időzítése kulcstényező lehet ebben: a regionális választások a vizsgált időszakban körül-belül hat hónappal a parlamenti után voltak, amely - hacsak nem történik valami váratlan, erőviszonyokat alapvetően felborító esemény (mint 2006-ban) - nem elegendő idő ahhoz, hogy a választópolgárok a kormánypárt tevékenységéről protesztszavazatok formájában mondjanak véleményt.

Összességében, Magyarországon inkább a „,top-down” jellegü folyamat (nacionalizáció) érvényesül, az országos pártok egyre meghatározóbb szereplők, egyre inkább egyeduralkodók a középszinten is, az intézményrendszer változása és az országos pártok szövetségi politikája

\footnotetext{
${ }^{1} \mathrm{Ha}$ úgy tetszik, az elemzés ezzel a megközelítéssel visszatér a magyar önkormányzati rendszer azon, rendszerváltás idején feltett kérdéséhez, hogy miről szól a helyi politika: az országos pártokról vagy a helyi szervezetekről?
} 
is az alulról jövő kezdeményezések visszaszorulásának irányába hatnak. Magyarország ezzel illeszkedik a közép- és kelet-európai országok sorába a regionális politika terén, melyek esetében a regionális szint nacionalizációja az uralkodó trend: a másodrendű választás jellemzői érvényesülnek, mivel a választók, a politikusok a politikai pártok és a média is alacsony téttel bíró, országos politikai keretben értelmezett voksolásnak tekintik a választásokat (Schakel Dandoy 2017: 17).

3. ábra: Szavazatarányok változása pártcsoportok szerint (1994-2010)

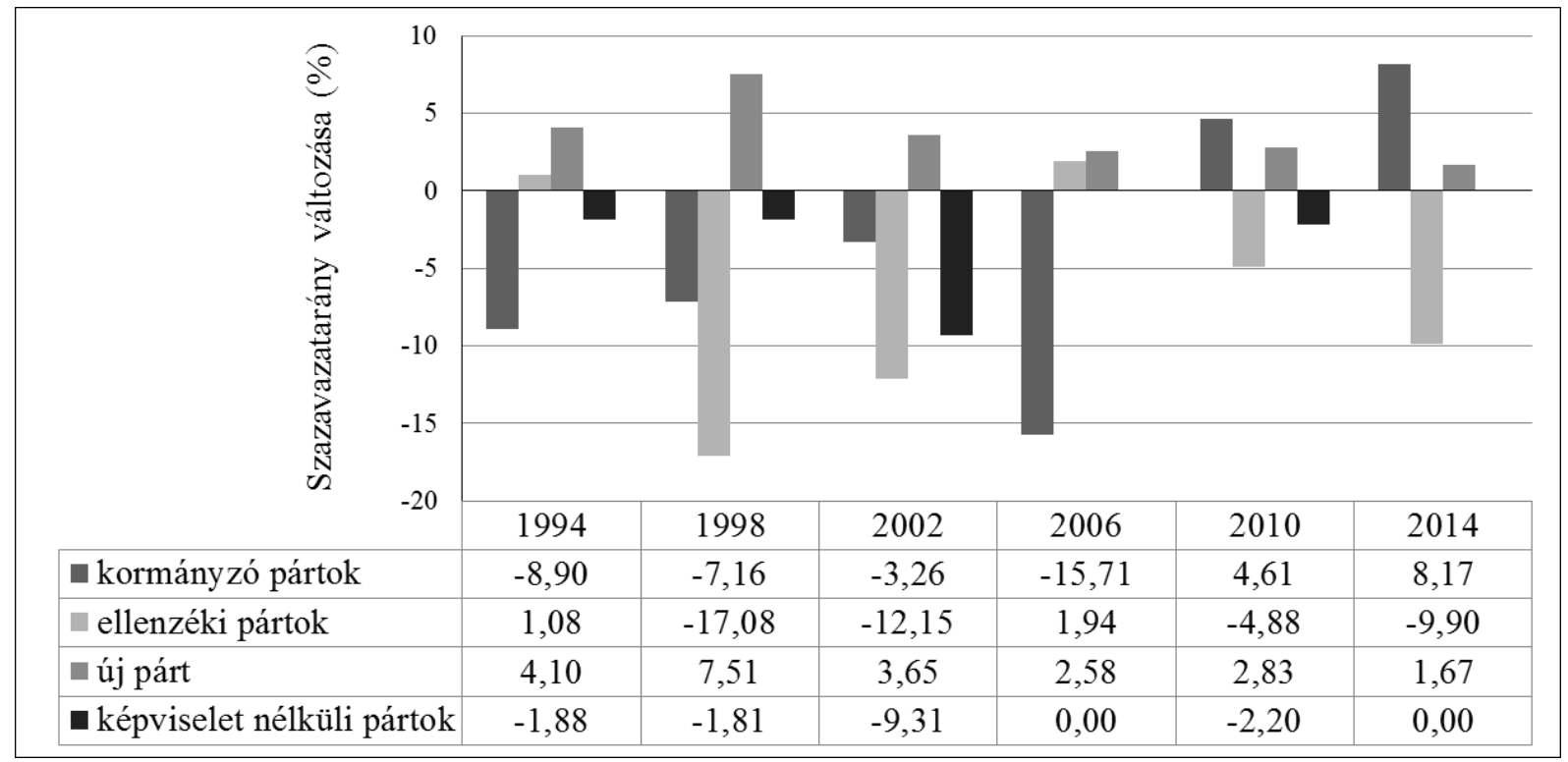

Természetesen, a szervezeti szereplők elemzése a választási eredmények felől nem ad teljes képet a helyi politikai autonómiáról, ehhez a helyi pártszervezetek belő müködését feltáró kvalitatív kutatásra lenne szükség. Ennek hiányában feltételezésekkel lehet csak élni a helyi szervezetek autonómiáját illetően - mely feltételezéseket a helyi egyéni szereplök viszonyainak feltérképezése céljából használt kvantitatív és kvalitatív kutatások is részben alátámasztanak. Eszerint 2010 után még jobban felerősödtek azok a folyamatok, amelyek már korábban is érzékelhetőek voltak: az önkormányzatok irányítása (a kis falvak kivételével) az országos pártok kezébe került (Pálné 2008: 242), így ugyanaz a politikai logika érvényesül helyi szinten, ami az országos pártpolitikai viszonyokat meghatározza. A helyi politika müködése tehát 
elsősorban pártkérdés, és ez az adott politikai helyzetben ${ }^{2}$ feltételezhetően politikai centralizációt jelent.

\section{III.3. A helyi politika egyéni szintje - horizontális viszonyok}

Az elemzés harmadik szintjén, a helyi szereplők horizontális viszonyrendszerének empirikus elemzése során a dolgozat kvantitatív és kvalitatív megközelítést is alkalmaz. Az egyéni szereplők horizontális viszonyrendszerét (illetve annak változásait) feltáró) elemezés első levonható következtetése az, hogy helyi szinten sokat számítanak a szereplők egyéni jellemzői. A helyi politikában a polgármester szerepe kiemelt, illetve esetenként jelentősége lehet az alpolgármesteri pozíciónak is. A harmadik fontos szereplő, a jegyző súlya az önkormányzati reform nyomán csökkent, a polgármesterhez való kötöttség miatt a lojalitás különösen fontos tulajdonsággá vált a pozíció betöltéséhez.

A 2010 utáni helyzet, az átalakulás megragadására vonatkozó empirikus kutatások alapján, két területen hozott változást. Egyrészt az adott pártpolitikai helyzetben (a Fidesz-KDNP túlsúlya nyomán a képviselö-testületekben) a döntéshozatal fókusza áttevődött a képviselő-testületből a pártfrakcióba, a testület csak szentesíti a frakcióban kialakított többségi döntést. Másrészt, a polgármester pozíciója a formális szabályok alapján erősödött, és a percepciókara vonatkozó kutatás is ezt igazolja vissza. A horizontális kapcsolatokat vizsgálva az látható, hogy a két adatfelvétel között fontosabbá váltak az adminisztráció számára a politika által meghatározott célok, és a polgármesterek egyre inkább úgy gondolják, hogy nem csak az adminisztráció által követendő célok kijelölése, de a megvalósítás módjának a meghatározása is feladatuk. Azt mondhatjuk tehát, hogy a kétezres években a politika és adminisztráció közelebb került egymáshoz, a politika (és azon belül is polgármester) egyre nagyobb hatással van az adminisztráció müködésére. A polgármesternek a helyi politika horizontális kapcsolataiban elfoglalt helyének erősödését támasztja alá az is, hogy nemcsak az adminisztrációval, de más helyi politikai szereplőkkel szemben is erősíteni tudta a pozícióját (4. ábra). Ezzel szemben a vertikális viszonyok vizsgálata azt mutatja, hogy az országos szint és az országos politika szereplői a helyi szereplők rovására egyre növekvő befolyással rendelkeznek a helyi ügyek irányításában (1. táblázat).

\footnotetext{
${ }^{2}$ A nagyobb kormányzó párt, a Fidesz politikai szervezete és döntéshozatala rendkívül centralizált (Horváth és Soós 2015: 275; Balázs és Hajdú 2017: 95), ebből következően pedig a pártvezetés szerepe a helyi szervezetek tevékenységében és a helyi politika alakításában is jelentőséggel bír.
} 
4. ábra: Az egyes szereplök informális befolyása az önkormányzat életére

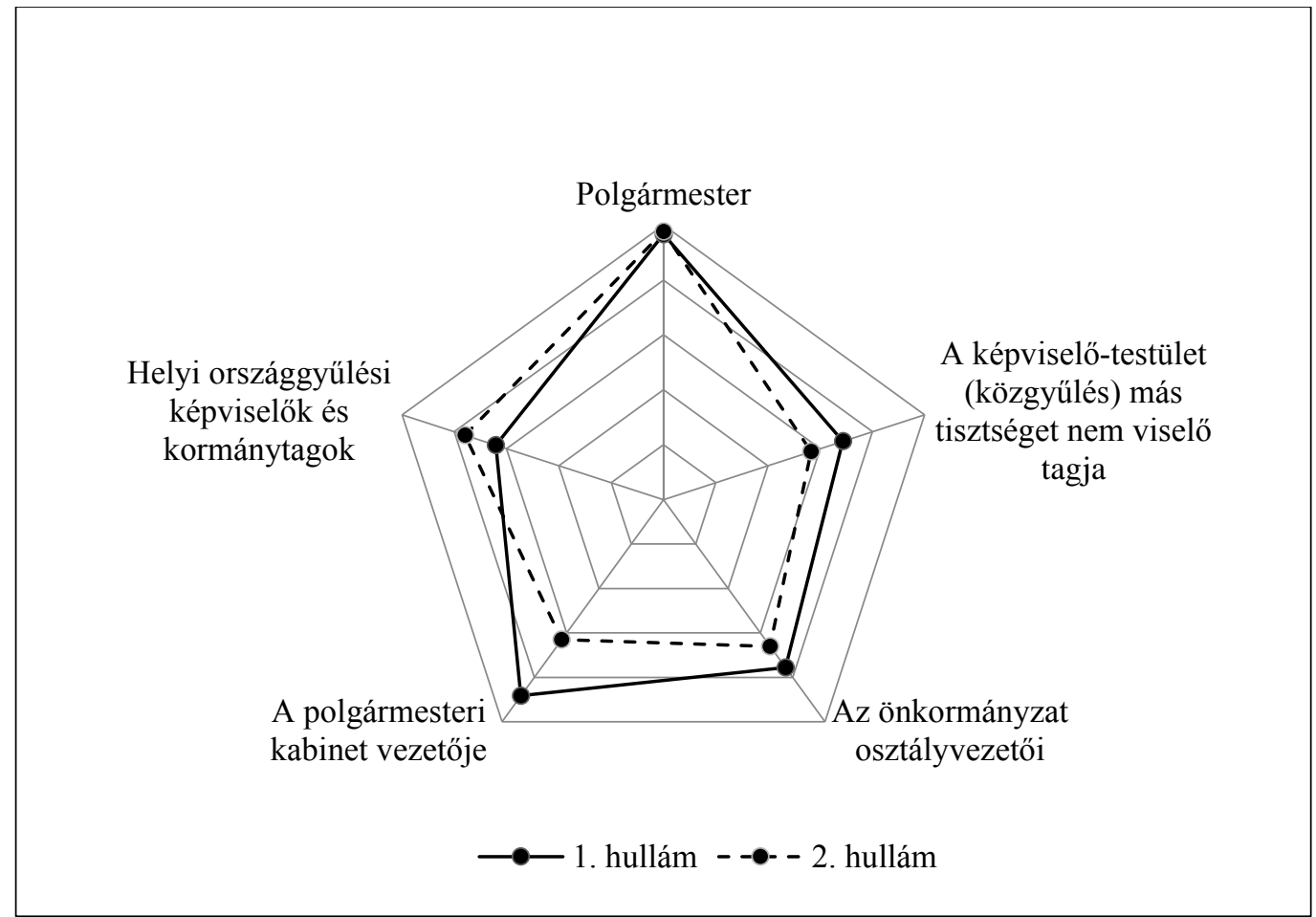

Adatok: „Political Leaders in European Cities” (POLLEADER) kérdöíves felmérés elsö (2003) és második (2015) hulláma

1. táblázat: Az adatfelvételek (2003 és 2015) elötti egy évtizedben végbemenö változások a különbözö szintek és szereplök viszonylatában

\begin{tabular}{|l|c|c|}
\cline { 2 - 3 } \multicolumn{1}{c|}{} & 1. hullám & 2. hullám \\
\hline Helyi szint - Országos szint (vertikális viszonyok) & 3,2 & 4,6 \\
\hline $\begin{array}{l}\text { Polgármester - Képviselö-testület/Közgyülés (horizontális } \\
\text { viszonyok) }\end{array}$ & 3,23 & 3,25 \\
\hline
\end{tabular}

Kérdés: "Eddigi helyi politikában szerzett tapasztalatai alapján hogyan jellemezné az elmúlt évtizedben végbement változásokat, ami a helyi ügyekben érintett szereplők befolyását illeti?"

Adatok: „Political Leaders in European Cities” (POLLEADER) kérdöives felmérés elsö (2003) és második (2015) hulláma

A nemzetközi kutatási keretben megvalósuló, kérdőíves felmérésen alapuló (kvantitatív) kutatás a helyi szint szereplői kapcsán a hasonlóságok feltérképezésére alkalmas. A kutatás megmutatja, hogy az intézményi változások megjelennek az önkormányzatok kiemelt szereplőinek, a polgármestereknek a percepcióiban is, akik egyszerre számolnak be saját pozíciójuk erősödéséről és a helyi politika csökkenő erejéről az országoshoz képest. A 
harmadik elemzési szinten végzett, interjúkon alapuló (elsősorban kvalitatív) kutatás a különbségeket hangsúlyozza, bemutatja, hogy az egyedi helyi sajátosságok milyen meghatározóak tudnak lenni. Igaz ez az aktorok személyes jellemzőire (így például a polgármesternek, az alpolgármesternek illetve a jegyzőnek a karakterére), de igaz az önkormányzatokra magukra is.

A helyi szereplök horizontális viszonyrendszerének és az önkormányzati átalakítás alulnézeti képének empirikus elemzése rámutat arra, hogy a helyi autonómia erősen függ a települések komplex (gazdasági-társadalmi) helyzetétöl. Mindez azt jelenti, hogy ugyanabban az intézményi keretben többféle autonómia is müködhet, a települési sajátosságoktól függően azaz, ha a felülnézeti kép mellé alulnézeti megközelítést is társítunk, nincs egzakt válasz arra, hogy a magyarországi önkormányzati rendszer autonómiája milyen. Az az önkormányzat erősebb autonómiával fog bírni, amelyiknek nagyobb a müködési mozgástere - ez pedig az empirikus elemzés (az önkormányzati reform helyi szereplők általi értékelése) alapján leginkább az önkormányzatok pénzügyi helyzetével függ össze. Akkor beszélhetünk valódi (a szakirodalomban a kezdeményezés és immunitás hatalmával leírt) autonómiáról, ha a politikai autonómia mellé pénzügyi függetlenség is társul, azaz a központi kormányzat a feladatokhoz és a döntéshozatali önállósághoz pénzügyi eszközöket is biztosít, az adott szint független működésének a politikai/intézményi és a pénzügyi garanciái egyaránt adottak. Ennek alapján látható, hogy az autonómia nem olyan „statikus” fogalom, amilyennek a makró szintű változók leírják, hanem nagyban függ az önkormányzatok mindenkori egyéni jellemzőitől, mindenekelőtt a települések gazdasági fejlettségétől. A makró szintű változók alkalmazhatóságának korlátaival kapcsolatban ez az egyik legfontosabb tanulság: ahhoz, hogy pontosabb képet kapjunk az önkormányzati rendszer autonómia-szintjéről, szofisztikáltabb megközelítésre van szükség, amely nem veszi „egy kalap alá” az összes települést, hanem differenciál az önkormányzatok között különböző adottságok (méret, társadalmi-gazdasági fejlettség stb.) alapján.

Összességében, dolgozatomban több szempontból is igyekszem új eredményekkel gazdagítani a magyar önkormányzati rendszer autonómiájával kapcsolatos tudományos ismereteket. A téma megközelitését tekintve amellett foglalok állást, hogy az intézményi keretekböl kiinduló vizsgálat mellett fontos a gyakorlati müködést a szereplőkön keresztül megragadni próbáló, neo-institucionalista értelmezés is. Ebböl következően, fogalmi szempontból az autonómiát kiterjesztő értelmezésben kell használni, az intézményi berendezkedés és a müködési mozgástér (feladatellátási szabadság, pénzügyi függetlenség) mellett a rendszer és szereplőinek politikai 
önállósága is meghatározó a helyi autonómia szempontjából. Ahhoz, hogy ezt a komplex autonómia-felfogást empirikusan elemezni lehessen, módszertani szempontból a vegyes, kvantitatív és kvalitatív megközelítést egyaránt tartalmazó vizsgálati mód alkalmazása célszerü, mely több perspektívából (a felülnézeti és alulnézeti kép egymás mellé helyezésével) képes megragadni a kutatási témát. Végül, a magyar önkormányzati rendszert három szinten vizsgáló empirikus elemzés eredménye, hogy a helyi és megyei önkormányzatok jelentősége a magyar politikai rendszerben a 2010-töl csökkent, az önkormányzatok autonómiája formálisan megmaradt, de a gyakorlati müködésben (legyen az feladatellátás, pénzügyi helyzet vagy a politika működésének logikája) az önállóságuk visszaszorult. Ahogyan a dolgozatból ugyanakkor kiderül, e rendszerszinten érvényes megállapításon túl, eltérő társadalmi-gazdasági helyzetükből adódóan az egyes önkormányzatok más-más valódi autonómia-szinttel rendelkezhetnek. 


\section{Hivatkozások}

Balázs Zoltán - Hajdú András (2017): A Fidesz - Magyar Polgári Szövetség a magyar politikában, in Boda Zsolt-Szabó Andrea (szerk): Trendek a magyar politikában 2. - A Fidesz és a többiek: pártok, mozgalmak, politikák, Budapest: MTA Társadalomtudományi Kutatóközpont

Dobos Gábor, Várnagy Réka (2017): Hungary: Are Neglected Regional Elections SecondOrder Elections? In: Arjan H Schakel (szerk.): Regional and National Elections in Eastern Europe: Territoriality of the Vote in Ten Countries. London: Palgrave Macmillan, pp. 105-128.

Heinelt, Hubert (2010): Governing Modern Societies, London - New York: Routledge

Hooghe, Liesbet - Marks, Gary - Schakel, Arjan H. (2010): The rise of regional authority: a comparative study of 42 countries, London: Routledge

Horváth Attila - Soós Gábor (2015): Pártok és pártrendszer, in Körösényi András (szerk.): A magyar politikai rendszer - negyedszázad után, Budapest: Osiris

Johnson, Burke - Onwuegbuzie, Anthony - Turner, Lisa A. (2007): Toward a Definition of Mixed Methods Research, Journal of Mixed Methods Research, 2007:1, 112-133.

Király Gábor - Dén-Nagy Ildikó - Géring Zsuzsanna - Nagy Beáta (2014): Kevert módszertani megközelítések - elméleti és módszertani alapok, Kultúra és Közösség, 5:(2), 95-104.

Ladner, Andreas - Keuffer, Nicolas - Baldersheim, Harald (2016): Measuring Local Autonomy in 39 Countries (1990-2014), Regional and Federal Studies, 26:(3), 321-357.

Lowndes, Vivien (2001): Rescuing Aunt Sally: Taking Institutional Theory Seriously. Urban Politics, 38:(11), 1953-1971.

Page, Edward C. - Goldsmith, Mike (1987): Central and Local Government Relation, Beverly Hills: Sage

Pálné Kovács Ilona (2008): Helyi kormányzás Magyarországon, Pécs: Dialóg Campus Kiadó

Pedersen, Morgens N. (1979): The Dynamics of European Party Systems: Changing Patterns of Electoral Volatility, European Journal of Political Research, 7:(1), 1-26.

Schakel, Arjan H. (szerk.) (2017): Regional and National Elections in Eastern Europe. Territoriality of the Vote in Ten Countries, Basingstoke: Palgrave Macmillan

Schakel, Arjan H. - Dandoy, Régis (2017): Conclusion: Towards an Explanation of the Territoriality of the Vote in Eastern Europe, in Schakel (szerk.): Regional and National Elections in Eastern Europe. Territoriality of the Vote in Ten Countries, Basingstoke: Palgrave Macmillan 
Soós Gábor (2008): Local and National Parties in Hungary, in Reiser - Holtmann (szerk): Farewell to the Party Model? Independent Local Lists in East and West European Countries, Wiesbaden: Springer VS

Soós Gábor (2015): Local Government Institutionalization in Hungary, Frankfurt am Main: Peter Lang Verlag

Sweeting, David (2008): New Institutionalism and Local Political Management is Spain. Working Paper Online Series

https://tinyurl.com/sweeting-paper

Letöltés dátuma: 2018. február 1.

Tóth Adrienn (2013): Országos pártok - helyi önkormányzatok, Politikatudományi Szemle 22:(3), 117-137.

\section{A szerző témában megjelent publikációi}

Dobos Gábor, Várnagy Réka (2017): Hungary: Are Neglected Regional Elections SecondOrder Elections? In: Arjan H Schakel (szerk.): Regional and National Elections in Eastern Europe: Territoriality of the Vote in Ten Countries. London: Palgrave Macmillan, pp. 105-128.

Dobos Gábor, Papp Zsófia (2017): Változó intézmény, változó szerepek: a magyar önkormányzati rendszer átalakulása a polgármesterek szemüvegén keresztül In: Boda Zsolt, Szabó Andrea (szerk.): Trendek a magyar politikában 2. A Fidesz és a többiek: pártok, mozgalmak, politikák. Budapest: MTA TK PTI - Napvilág Kiadó, pp. 61-82.

Dobos Gábor (2016): Changing Local Relations: Effects of the 2010-2014 Political and Administrative Reforms in Hungary In: Mariusz Wiktor Sienkiewicz, Katarzyna KucCzajkowska (szerk.): Local Government in selected Central and Eastern European Countries: Experiences, Reforms, and Determinants of Development. Lublin: Maria Curie-Skłodowska University Press, 2016. pp. 73-90.

Várnagy Réka, Dobos Gábor (2012): Ki az úr a háznál? Döntéshozatal a magyar önkormányzati rendszerben. Pro Publico Bono: Állam-és Közigazgatástudományi Szemle 2012:(1) pp. 130146.

Dobos Gábor (2011): Elmozdulás középszinten: A 2010-es önkormányzati választási reform hatásai a megyei önkormányzatokra. Politikatudományi Szemle 20:(4) pp. 61-83. 